\title{
Central Nervous System Effects of COVID-19 in People with HIV Infection
}

\author{
Michael J. Peluso ${ }^{1}$ (1) $\cdot$ Joanna Hellmuth $^{2} \cdot$ Felicia C. Chow $^{3,4}$
}

Accepted: 8 September 2021 / Published online: 29 November 2021

(c) The Author(s) 2021

\begin{abstract}
The convergence of the HIV and SARS-CoV-2 pandemics is an emerging field of interest. In this review, we outline the central nervous system (CNS) effects of COVID-19 in the general population and how these effects may manifest in people with HIV (PWH). We discuss the hypothetical mechanisms through which SARS-CoV-2 could impact the CNS during both the acute and recovery phases of infection and the potential selective vulnerability of PWH to these effects as a result of epidemiologic, clinical, and biologic factors. Finally, we define key research questions and considerations for the investigation of CNS sequelae of COVID-19 in PWH.
\end{abstract}

Keywords HIV $\cdot$ SARS-CoV-2 $\cdot$ COVID-19 $\cdot$ Central nervous system

As the severe acute respiratory syndrome-coronavirus-2 (SARS-CoV-2) pandemic continues, millions of individuals worldwide remain at risk for coronavirus disease 2019 (COVID-19). The convergence between the HIV and SARS-

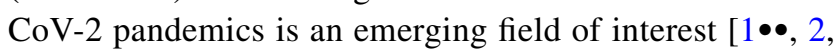
3]. Attention is needed on the effects of this novel infection on the large global population of people with HIV (PWH) — nearly 38 million people worldwide [4], many of whom will remain vulnerable to infection with SARS-CoV-2 for the foreseeable future.

HIV infection, even when well-controlled with antiretroviral therapy (ART), has long-term implications on health through mechanisms related to viral persistence, chronic

This article is part of the Topical Collection on Central Nervous System and Cognition

Felicia C. Chow

felicia.chow@ucsf.edu

1 Division of HIV, Infectious Diseases, and Global Medicine, University of California, San Francisco, CA, USA

2 Memory and Aging Center, Weill Institute for Neurosciences, Department of Neurology, University of California, San Francisco, CA, USA

3 Weill Institute for Neurosciences, Departments of Neurology and Medicine (Infectious Diseases), University of California, San Francisco, CA, USA

4 San Francisco General Hospital, 1001 Potrero Avenue, Building 1, Suite 101, CA, San Francisco, USA inflammation, and incomplete immune reconstitution [5-11]. The central nervous system (CNS) is particularly vulnerable, due to the effects of HIV both systemically and within the CNS $[9,12-16]$. This vulnerability may increase the neurologic effects of COVID-19 among PWH. Growing evidence indicates that the CNS can be impacted by SARS-CoV-2 infection, during both the acute and recovery phase of COVID-19 [17, $18,19 \bullet, 20-23]$. However, it is currently unknown if $\mathrm{PWH}$ are selectively vulnerable to the CNS effects of SARS-CoV-2 infection, and if so, whether certain interventions (e.g., vaccination, COVID-19 targeted therapies) can mitigate them. In this article, we review the potential CNS effects of COVID-19 in PWH with a focus on proposed mechanisms, key research questions, and considerations for how to approach their investigation.

\section{Acute CNS Complications of COVID-19 in the General Population}

A wide range of neurologic disorders has been observed in acute SARS-CoV-2 infection. However, most studies have focused on hospitalized patients, and less is known about the prevalence and spectrum of neurologic symptoms in COVID-19 patients who do not require hospitalization. In a UK surveillance study of 125 case notifications for neurologic and psychiatric complications among hospitalized COVID-19 patients over a 3-week period, altered mental 
status and cerebrovascular disease constituted the majority of syndromes reported [24]. Neurologic involvement during acute SARS-CoV-2 infection may be more common in older individuals or in those with severe illness [25, 26•]. In one study of 58 critically ill patients in the intensive care unit (ICU) in France, agitation and/or confusion were present in $69 \%$ when sedation was lifted [27]. One-third of patients had evidence of ongoing altered mental status at the time of discharge. The presence of neurologic manifestations in acute SARS-CoV-2 infection may also predict higher in-hospital mortality independent of age and disease severity [28].

It may be challenging to differentiate encephalopathy due to the direct or indirect effects of SARS-CoV-2 infection from the impact of critical illness, prolonged ICU hospitalization, and other medical issues (e.g., metabolic derangements, medication toxicity) on the brain. While some degree of encephalopathy is prevalent in hospitalized patients with COVID-19, encephalitis, defined as inflammation of the brain parenchyma by neuroimaging or cerebrospinal fluid [CSF] analysis, occurs infrequently [29-31]. In brain autopsy studies, mild non-specific inflammation (e.g., perivascular, parenchymal, and leptomeningeal lymphocytic infiltrates), acute hypoxic-ischemic injury, and microvascular changes are commonly reported, whereas frank vasculitis or meningoencephalitis are not [32, 33•, 34].

Mounting evidence points to elevated cerebrovascular risk during acute SARS-CoV-2 infection. In a study of 1916 patients who were hospitalized or sought emergency care at a single center in New York City over 2 months, 31 (1.6\%) had an acute ischemic stroke compared with 3 of 1486 influenza patients (0.2\%; derived from historical data) [35]. Similar to other neurologic complications of COVID-19, patients who develop cerebrovascular disease may be older and more likely to suffer from cardiometabolic comorbidities (e.g., hypertension, diabetes mellitus) and from more severe SARS CoV-2 infection [36]. In contrast, other studies have raised the specter of an association between asymptomatic or mild SARS-CoV-2 infection and elevated stroke risk in the young $[37,38]$.

\section{Neurologic Post-acute Sequelae of COVID-19 (PASC) in the General Population}

Following acute illness, an unknown but likely substantial number of people experience post-acute sequelae of SARSCoV-2 infection (PASC) [17]. Initially identified in convenience samples [18, 19•, 39-41], efforts have been made to estimate the prevalence of PASC in more representative samples, although these have typically involved short followup $[42,43]$ or have been limited to hospitalized patients [44, $45 \bullet \bullet$. Recently, preliminary data on the frequency of PASC have emerged in larger and more representative cohorts
[46, 47], although true population-level studies are urgently needed. Post-acute neurologic sequelae include cognitive changes, sleep disorders, headache, neuropathy, tinnitus, vertigo, dysgeusia, anosmia/phantosmia, and dysautonomia; mood symptoms are also common [18, 39-41, 46-48].

Persistent cognitive changes are a predominant feature of CNS PASC. People can experience new difficulties staying focused (attention), holding onto and manipulating information (working memory), remembering recent events that improves with cues (executive function), and slowed thinking (processing speed). Collectively, these symptoms suggest fronto-executive brain network dysfunction. Cognitive difficulties now reported in several cohorts [39-41], including in non-hospitalized individuals $[18,19 \bullet]$, can persist longer than 8 months [39]. Importantly, there appears to be a considerable impact on quality of life [19•, 39], which corroborates patient-driven descriptions of PASC [49]. A clear underlying mechanism or therapeutic approach has yet to be identified.

\section{Neurologic Effects of COVID-19 in People with HIV}

While there was initial concern that PWH would exhibit increased vulnerability to SARS-CoV-2 infection based on greater susceptibility to other respiratory pathogens $[2,50]$, studies to date have found comparable or lower incidence of COVID-19 among PWH [3, 51-54]. Although early studies suggested that PWH were at similar risk for severe COVID19 as those without HIV infection [55-58], further efforts have indicated that those with a higher burden of medical comorbidities and/or incomplete immune reconstitution are likely to be at increased risk for more severe outcomes [59, 60]. No data are currently available on the clinical manifestations of the post-acute phase of SARS-CoV-2 infection and COVID-19 recovery in PWH, although studies are underway [61].

\section{Potential Mechanisms}

Overlap or synergy in potential mechanisms driving neurologic complications of COVID-19 and HIV may place PWH with COVID-19 at higher risk for CNS dysfunction and/or injury (Fig. 1). Of particular interest is how cognitive changes associated with COVID-19 may be similar to and interface with the virally mediated cognitive disorder of HIV, known as HIV-associated neurocognitive disorder (HAND). The clinical presentation of HAND, which may impact up to one-third of PWH on ART [62], is strikingly similar to the executive dysfunction seen following COVID19 [63]. However, one notable difference between patients with COVID-19 and HIV-associated cognitive impairment 
Fig. 1 Summary of the potential overlap between known or suspected mechanisms underlying central nervous system manifestations of SARS-CoV-2 and HIV infection

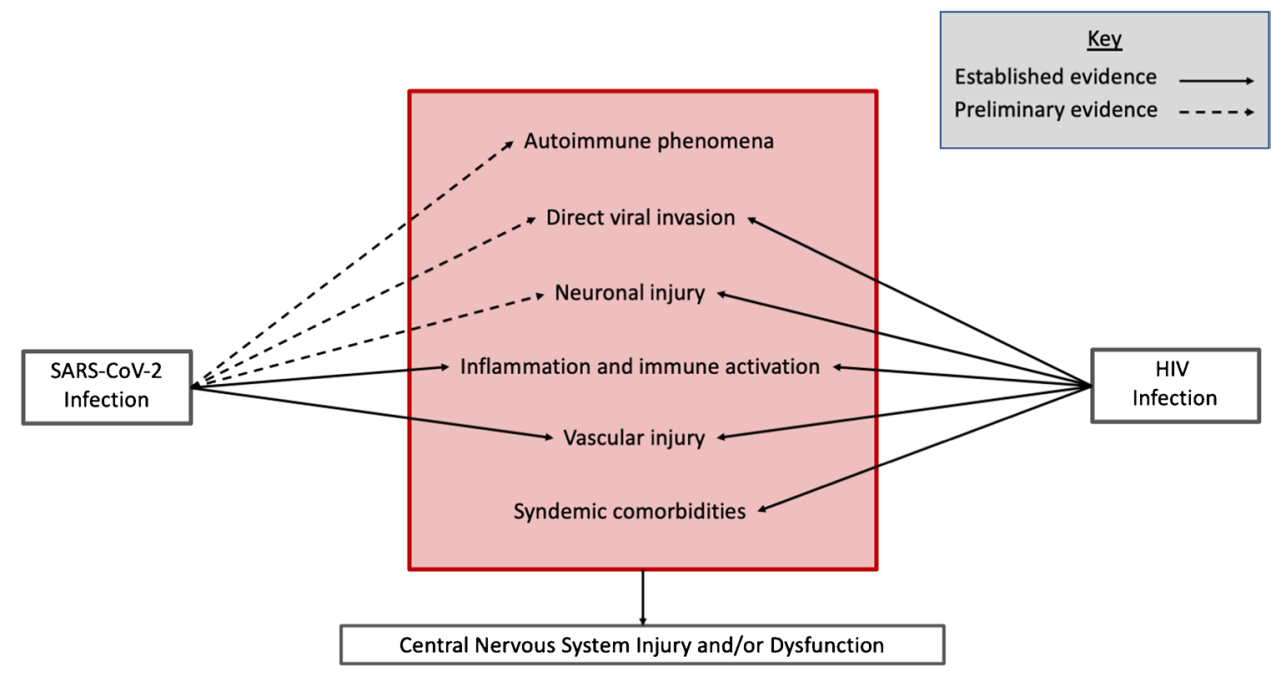

is the temporal onset of symptoms. Based on our current knowledge, cognitive changes appear acutely or within the first few months following COVID-19, while HAND can develop after years of sustained viral suppression on antiretroviral therapy. This may hint at a critical distinction between the impact of these two viruses on the CNS. HIV causes a chronic infection and persists in latently infected cells in reservoirs established early in infection, including in the CNS. The presence of persistent HIV-infected cells in CSF has been linked to worse cognition in PWH [64]. In contrast, while we are still early in our understanding of the trajectory of SARS-CoV-2 infection and the potential for viral persistence [65], including in immunocompromised patients [66, 67] and patients with severe disease [68], most patients appear to be able to effectively clear SARS-CoV-2 infection. However, if SARS-CoV-2 can persist in the CNS long term, as has been shown for other human coronaviruses $[69,70]$, the prospect of ongoing neurologic injury and delayed neurologic dysfunction may be greater. Furthermore, mechanisms underlying encephalopathy in the setting of acute SARS-CoV-2 infection may diminish existing cognitive reserves and unmask or magnify cognitive impairment in PWH. In our own clinical practice, some patients with HAND have reported worsening of cognitive symptoms following COVID-19.

Preliminary data and expert opinion suggest that one or more of several mechanisms might contribute to the potential neurologic effects of COVID-19 in PWH:

1. Altered immune response, inflammation, and immune activation: Systemic and CNS inflammation and immune activation, which can remain elevated in $\mathrm{PWH}$ even after viral suppression with ART [71-74], have been implicated in the pathogenesis of complications associated with long-term HIV infection, including HAND [75-77]. Activation of inflammatory pathways in acute SARS-CoV-2 infection could compound the impact of chronic inflammation on the CNS in $\mathrm{PWH}$ [78-80]. One study demonstrated marked intrathecal inflammation, measured by CSF neopterin and $\mathrm{b}_{2}$-microglobulin, in hospitalized patients with COVID19 and neurologic symptoms, although CSF pleocytosis, elevated IgG index, and evidence of blood-brain barrier disruption were absent [81]. Furthermore, immune activation and inflammation, either systemically or in the tissues, may persist after acute COVID-19 [17, 39]. Levels of soluble markers of inflammation (e.g., interleukin-10 (IL-10), macrophage-inflammatory protein-1, interferon-inducible protein -10 (IP-10)) have been shown to be elevated in SARS-CoV-2 convalescent plasma donors compared with healthy blood donors without COVID-19 [82•]. If this is the case, ongoing immune dysregulation may contribute to post-COVID cognitive changes, to which PWH might be particularly susceptible.

2. Direct viral invasion and neuronal injury: Post-mortem and human brain organoid studies have demonstrated direct SARS-CoV-2 invasion into the CNS with resulting neuronal death $[33 \bullet, 83 \bullet, 84]$. In one postmortem study, SARS-CoV-2 infection was identified in areas of cerebral microinfarcts, raising the possibility that direct viral invasion may contribute to CNS injury and neurologic symptoms in COVID-19 [83•]. However, despite evidence of neuroinvasive potential of SARS-CoV-2, we do not yet know the frequency of this and the precise relationship between neuroinvasion and the development of acute and post-acute neurologic sequelae.

Whereas identification of SARS-CoV-2 RNA from CSF has been rare $[30,81,84,85 \bullet]$, HIV RNA is readily measured in the CSF within days to weeks of infection $[15,86]$ and in persons with untreated chronic infection [87]. The degree of CNS injury related to direct viral 
invasion, immune activation, and neuroinflammation may be dictated by events during acute HIV infection, similar to the establishment of an immune set point early in HIV infection, which predicts later decline and disease progression. Very early ART initiation may mitigate HIV-associated CNS injury [88, 89], although this is often not logistically feasible, and risk for HAND persists even with sustained viral suppression [90].

The presence and severity of HAND is associated with markers of brain injury, including neurofilament light chain (NFL), a protein present in myelinated axons of neurons [91, 92]. Similarly, in a study of hospitalized patients with moderate to severe COVID-19, NFL and/ or glial fibrillary acidic protein (GFAP), an astroglial injury/activation marker, were elevated [93•]. This finding implies that CNS injury, rather than dysfunction of intact brain cells, occurs in some patients with moderate-to-severe COVID-19. The clinical consequences of this injury, which may be related to direct viral invasion or other mechanisms (e.g., persistent immune activation), could be especially relevant to $\mathrm{PWH}$ with ongoing HIV-related neurologic injury.

3. Post-infectious autoimmunity: Given the infrequent detection of SARS-CoV-2 neuroinvasion, some data suggest that CNS injury or dysfunction is caused by immune-mediated mechanisms that occur secondary to systemic infection. A recent study found that 5 of 7 hospitalized COVID-19 patients with a spectrum of neurologic issues displayed evidence of CNS autoantibodies [23]. Further work is needed to ascertain whether autoimmunity plays a role in PASC. Autoimmune phenomena are sometimes associated with the immune dysregulation that characterizes HIV infection [93•, 94-96], and it is unknown whether the autoimmune risk in SARS-CoV-2 is modified by HIV infection.

4. Neurovascular injury: The long-term projections for brain health and recovery after SARS-CoV-2 infection may be influenced by mechanisms driving neurovascular risk during acute infection, including a dysfunctional immunologic and endothelial response triggering cerebral microvascular injury and thrombosis [34]. Furthermore, subclinical microvascular injury triggered by acute infection may not become clinically apparent until later in the course of recovery. As has been shown with other systemic infections [97, 98], cerebrovascular risk associated with COVID-19 may also remain elevated beyond the acute period.

The proposed mechanisms by which SARS-CoV-2 may lead to elevated cerebrovascular risk may be particularly relevant for PWH. PWH contend with a heightened risk of cerebrovascular injury, attributed in part to chronic systemic immune activation and inflammation $[7,9]$. Cerebrovascular disease and associated cardio- vascular comorbidities, in turn, are major contributors to HIV-associated cognitive impairment. In fact, cardiovascular risk factors may play a greater role in the development of cognitive impairment than HIV disease activity [99, 100], especially among individuals with treated infection. Thus, for PWH, the immunologic and inflammatory response to COVID-19 may serve as an unwelcome "second hit," further compounding cerebrovascular risk and cognitive injury in this at-risk population. Studies have supported the concept of a cumulative infectious burden contributing to cerebrovascular risk, in which individual infections may not surpass thresholds to impact stroke risk but several infections in aggregate can [101].

5. Syndemic comorbidities: Syndemic comorbidities in PWH, including substance use and metabolic disorders, may increase risk for contracting SARS-CoV-2 infection and lead to more severe disease and worse clinical outcomes $[1 \bullet \bullet, 102]$. These comorbidities may also contribute to the development of CNS injury in PWH with SARS-CoV-2 infection. Use of some substances has been linked to structural brain injury and long-term impairments in cognitive function in PWH [103, 104], even after initiation of ART [105]. PWH who use stimulants can experience challenges navigating the HIV care continuum, resulting in barriers to achieving and maintaining virologic suppression [106], which is critical to mitigating the inflammatory response in HIV. Furthermore, plasma and CSF inflammation and immune activation are heightened among PWH with a history of current and prior substance use [105, 107]. Amplification of immune dysregulation is one plausible mechanism by which substance use could increase susceptibility to CNS injury in PWH. Similarly, altered immune responses and chronic inflammation observed in metabolic disorders, including obesity and type 2 diabetes mellitus [108-110], are proposed contributing factors to increased risk of SARS-CoV-2 infection and of severe disease. As with substance use, these pathways, which may mediate the association between metabolic disorders and HAND [111], could also intensify CNS injury associated with COVID-19 in PWH.

\section{Key Considerations for Research}

Understanding the epidemiology and pathogenesis of neurologic complications of SARS CoV-2 infection will inform our approach to investigating potential CNS effects of COVID-19 in PWH. The optimal study approach will depend on the specific research questions that are of greatest interest to PWH and their providers. Although there are 
many potential questions related to CNS effects of COVID19 in PWH (Table 1), we believe four are key:

1. Are PWH more vulnerable to CNS effects of SARS$\mathrm{CoV}-2$ infection than the general population?

2. Are CNS manifestations of COVID-19 during the acute or recovery phase more severe or more persistent in PWH compared to people without HIV?

3. Are certain pathogenic mechanisms that underlie the CNS effects of SARS-CoV-2 infection potentiated in PWH?

4. Which interventions, including SARS-CoV-2 preventative or therapeutic interventions or HIV-targeting interventions, could mitigate the impact of neurologic complications of SARS-CoV-2 infection in PWH?

\section{Representative Sampling and Meaningful Comparator Groups}

While descriptive analyses can characterize acute and post-acute neurologic COVID-19 complications in PWH to inform further research efforts, calculating an accurate prevalence estimate of CNS complications will require large, representative cohorts. Such cohorts should be agnostic to the presence of neurologic symptoms at the time of enrollment to avoid selection bias. To date, many descriptions of COVID-19 and its sequelae have utilized case series or convenience samples, which may not capture the true frequency of neurologic manifestations. Similarly, a prevalence estimate of neurologic complications of COVID-19 within the population of $\mathrm{PWH}$ in a certain geographic region will require cohorts representative of the full spectrum of individuals with HIV infection who acquire SARS-CoV-2.

Equally important to the epidemiologic questions is the utilization of meaningful comparator groups. An ideal study design would include clinical and biologic data from prior to and following the SARS-CoV-2 pandemic. Large observational cohorts of HIV infection [112, 113] that include a subset of individuals who developed COVID-19 could be leveraged to conduct such studies. Studies that are unable to evaluate pre-COVID-19 timepoints in PWH will require thoughtfully selected comparator groups. Depending on the question for investigation, this might be people with COVID-19 without HIV infection, PWH without COVID19 , or people with neither a history of HIV nor SARS-CoV-2 infection. Substantial effort will be required to ensure that these comparator groups are constructed in a way that minimizes the risk of selection biases that could arise from differential forces driving recruitment and inclusion. In some settings, oversampling of certain groups may be needed to facilitate inclusion of comparator groups that are sociodemographically similar to those with HIV infection, especially in light of the changing HIV epidemic. In the USA, this might include purposeful oversampling of specific demographic groups (e.g., Black and Latinx individuals, women) or groups with certain risk factors (e.g., men who have sex with men, injection drug users). In addition, as the neurologic burden of HIV infection has been increasingly recognized in resource-limited settings, global populations must be included in these research efforts.

Table 1 Key research questions regarding CNS manifestations of SARS-CoV-2 infection in people with HIV infection

Epidemiologic questions

What is the case definition for CNS manifestations of SARS-CoV-2 infection?

What is the prevalence of CNS manifestations of SARS-CoV-2 infection in people with HIV?

Are CNS manifestations of SARS-CoV-2 infection more common, severe, and/or persistent in PWH compared with people without HIV?

What are the determinants of the presence, severity, and duration of CNS manifestations of SARS-CoV-2 infection in PWH? Do these differ from the determinants in people without HIV infection?

What are the predictors of the presence, severity, and duration of CNS manifestations of SARS-CoV-2 infection in PWH? Do these differ from the predictors in people without HIV infection?

Biologic questions

What biologic mechanisms underlie the CNS effects of SARS-CoV-2 infection?

Are certain pathogenic mechanisms that underlie the CNS effects of SARS-CoV-2 infection potentiated in PWH?

Are there unique pathogenic mechanisms that contribute to CNS effects of SARS-CoV-2 infection in PWH?

Does HIV virologic (i.e., suppressed or unsuppressed) and immunologic status (i.e., proximal or nadir CD4+ T cell count) affect the development of CNS effects of SARS-CoV-2 infection)?

Clinical science questions

Does SARS-CoV-2 vaccination or acute treatment mitigate the development of neurologic complications during the acute or post-acute phases of infection?

What interventions will be effective in managing and treating post-acute neurologic complications of SARS-CoV-2 infection in PWH? Are any interventions likely to uniquely benefit $\mathrm{PWH}$ ? 


\section{Data Sources and Quality of Measurements}

While electronic medical record (EMR)-derived data can be used to measure neurologic effects of COVID-19 among those hospitalized during the acute period, variability in access to care, provider assessments, symptom screening, and participant reporting will complicate the use of these data for non-hospitalized individuals and for all individuals during the post-acute period. In addition, the quality of measurements is relevant. Most existing studies have queried participant symptoms through self-report or interview. Few have included objective testing, which will require a combination of structured assessments, neurologic examination, and neuropsychological testing. In our experience, routine cognitive screening tests developed for the detection of dementia, such as the Montreal Cognitive Assessment and Mini-Mental State Examination, may not utilize sensitive enough thresholds to detect the cognitive inefficiencies observed following COVID-19, particularly as this population includes a younger age range of patients [17]. Collection of data on the abovementioned syndemic comorbidities, among other conditions that may co-occur with HIV infection (e.g., cardiovascular disease, psychiatric illness) and can affect brain health, will be pertinent to evaluating the independent contributions of COVID-19 to CNS injury and whether HIV modifies this relationship.

In line with the importance of studying populationbased cohorts that reflect the distribution of demographic and socioeconomic factors in communities affected by COVID-19, these considerations are also germane to the investigation of potential CNS effects of COVID-19. Some of these factors have been associated not only with risk of SARS-CoV-2 infection but also with differential outcomes during both the acute and recovery phases of COVID-19 $[47,114-116]$ and with the development or severity of HAND [117-119]. Selection of neuropsychological tests that can measure cognitive function across diverse populations will be critical in the assessment of cognitive effects of SARS-CoV-2 infection [120]. Furthermore, data on social determinants of brain health (e.g., nativity and acculturation; language; education; literacy; psychosocial stress; occupation; economic and financial status; residential characteristics) will be essential to accurately interpret neuropsychological test results [120]. Considerations of these factors and how they impact brain health have been pioneered for decades in HIV research [117, 121-123]. Drawing from lessons learned in international multi-site studies $[124,125]$ on the evaluation of cognitive function in PWH across countries, languages, and educational backgrounds will also inform the approach to cognitive testing in patients with COVID-19.

\section{Biologic and Advanced Clinical Measurements}

To understand the mechanisms driving neurologic involvement of SARS CoV-2 infection and interactions in PWH, we will need longitudinal data on systemic and CNS inflammation, neuronal injury, the presence of autoantibodies, and other biologic factors beyond the acute infection period. In addition to blood measurements, CSF analyses may be critical. For example, some patients with COVID-19 and neurologic complications have displayed differential inflammatory profiles in CSF compared with plasma, suggesting compartmentalized CNS immunologic responses may contribute to neurologic disease [23]. Available neuroimaging data in COVID-19 are almost exclusively in patients with acute SARS-CoV-2 infection [126, 127]. Information on neuroimaging findings in post-acute infection is limited. One study demonstrated volumetric and microstructural differences on brain MRI in patients with COVID-19 at 3 months after infection compared with age- and sex-matched controls without COVID-19 [128]. Neuroimaging techniques that assess longitudinal brain structure, function, and cerebrovascular physiology in the post-acute period may yield insights into the pathogenesis of CNS injury in COVID-19, as they have in the field of HIV [129-133].

\section{Representation of PWH in Therapeutic Studies}

Through intense community advocacy, PWH were included in initial SARS-CoV-2 vaccine trials [134-136], although the numbers were often small [137]. In order to understand the potential impact of SARS-CoV-2 preventative or therapeutic interventions on CNS sequelae of COVID-19 in PWH, PWH will need to be eligible for and engaged in clinical trials. Subgroup analyses should examine the effects of these interventions on PWH, who may exhibit distinct responses based on different underlying risks and comorbidities. Furthermore, studies of interventions for both symptom management and treatment that may be specific to PWH will need to be considered, designed, and implemented.

\section{Conclusion}

The convergence of the dual HIV and SARS-CoV-2 pandemics has highlighted the urgent need for research on potential interactions between these two infections. Much of our knowledge of how viruses impact the brain and brain function derives directly from HIV research. Leveraging research infrastructure and scientific methods developed over decades of effort in the fight against HIV has allowed for rapid, hypothesis-driven study of the CNS effects of COVID-19. Studies investigating the determinants of CNS effects of SARS-CoV-2 infection in PWH and whether HIV infection 
potentiates the mechanisms underlying these effects will further illuminate our understanding of virally-mediated CNS disease and could potentially improve the quality of life of millions of PWH worldwide.

Funding The authors acknowledge support related to this work from the following sources: NIH/NIAID T32 AI60530-12, NIH/ NIAID 3R01AI141003-03S1, NIH/NIAID R01AI158013, NIH R21TW010148, NIH/NIMH K23MH114724, NIH P30 AI027763, and the UCSF Resource Allocation Program.

\section{Declarations}

Conflict of Interest The authors declare no competing interests.

Open Access This article is licensed under a Creative Commons Attribution 4.0 International License, which permits use, sharing, adaptation, distribution and reproduction in any medium or format, as long as you give appropriate credit to the original author(s) and the source, provide a link to the Creative Commons licence, and indicate if changes were made. The images or other third party material in this article are included in the article's Creative Commons licence, unless indicated otherwise in a credit line to the material. If material is not included in the article's Creative Commons licence and your intended use is not permitted by statutory regulation or exceeds the permitted use, you will need to obtain permission directly from the copyright holder. To view a copy of this licence, visit http://creativecommons.org/licenses/by/4.0/.

\section{References}

Papers of particular interest, published recently, have been highlighted as:

- Of importance

$\bullet \bullet$ Of major importance

1.•• Eisinger RW, Lerner AM, Fauci AS. HIV/AIDS in the era of COVID-19: a juxtaposition of two pandemics. J Infect Dis. 2021. https://doi.org/10.1093/infdis/jiab114. Outlines key considerations regarding the potential convergence between the HIV and SARS-CoV-2 pandemics.

2. Johnston R. The first 6 months of HIV-SARS-CoV-2 coinfection: outcomes for 6947 individuals. Curr Opin HIV AIDS. 2021;16:54-62.

3. Brown LB, Spinelli MA, Gandhi M. The interplay between HIV and COVID-19: summary of the data and responses to date. Curr Opin HIV AIDS. 2021;16:63-73.

4. UNAIDS. Global HIV \& AIDS statistics - 2020 fact sheet. Available at: https://www.unaids.org/en/resources/fact-sheet. Accessed Apr 242021.

5. Hunt PW, Sinclair E, Rodriguez B, Shive C, Clagett B, Funderburg N, Robinson J, Huang Y, Epling L, Martin JN, et al. Gut epithelial barrier dysfunction and innate immune activation predict mortality in treated HIV infection. J Infect Dis. 2014;210:1228-1238.

6. Serrano-Villar S, Sainz T, Lee SA, Hunt PW, Sinclair E, Shacklett BL, Ferre AL, Hayes TL, Somsouk M, Hsue PY, et al. HIVinfected individuals with low CD4/CD8 ratio despite effective antiretroviral therapy exhibit altered $\mathrm{T}$ cell subsets, heightened
CD8+ T cell activation, and increased risk of non-AIDS morbidity and mortality. PLoS Pathog. 2014;10:e1004078.

7. Tenorio AR, Zheng Y, Bosch RJ, Krishnan S, Rodriguez B, Hunt PW, Plants J, Seth A, Wilson CC, Deeks SG, et al. Soluble markers of inflammation and coagulation but not T-cell activation predict non-AIDS-defining morbid events during suppressive antiretroviral treatment. J Infect Dis. 2014;210:1248-59.

8. Hsue PY, Lo JC, Franklin A, Bolger AF, Martin JN, Deeks SG, Waters DD. Progression of atherosclerosis as assessed by carotid intima-media thickness in patients with HIV infection. Circulation. 2004;109:1603-8.

9. Chow FC, Ma Y, Manion M, Rupert A, Lambert-Messerlian G, Bushnell CD, Cedars MI, Sereti I, Sorond FA, Hsue PY, et al. Factors associated with worse cerebrovascular function in aging women with and at risk for HIV. AIDS. 2021;35:257-66.

10. Parks MM, Secemsky EA, Yeh RW, Shen C, Choi E, Kazi DS, Hsue PY. Longitudinal management and outcomes of acute coronary syndrome in persons living with HIV infection. Eur Heart J Qual Care Clin Outcomes. 2020. https://doi.org/10.1093/ehjqc co/qcaa088.

11. McLaughlin MM, Ma Y, Scherzer R, Rahalkar S, Martin JN, Mills C, Milush J, Deeks SG, Hsue PY. Association of viral persistence and atherosclerosis in adults with treated HIV infection. JAMA Netw Open. 2020;3:e2018099.

12. Chow FC, Lyass A, Mahoney TF, Massaro JM, Triant VA, Wu $\mathrm{K}$, Berzins B, Robertson K, Ellis RJ, Tassiopoulos K, et al. Baseline 10-year cardiovascular risk scores predict cognitive function in older persons, and particularly women, living with human immunodeficiency virus infection. Clin Infect Dis. 2020;71:3079-85.

13. Marcus JL, Leyden WA, Chao CR, Chow FC, Horberg MA, Hurley LB, Klein DB, Quesenberry CP Jr, Towner WJ, Silverberg MJ. HIV infection and incidence of ischemic stroke. AIDS. 2014;28:1911-9.

14. Milanini B, Samboju V, Cobigo Y, Paul R, Javandel S, Hellmuth J, Allen I, Miller B, Valcour V. Longitudinal brain atrophy patterns and neuropsychological performance in older adults with HIV-associated neurocognitive disorder compared with early Alzheimer's disease. Neurobiol Aging. 2019;82:69-76.

15. Valcour V, Chalermchai T, Sailasuta N, Marovich M, Lerdlum S, Suttichom D, Suwanwela NC, Jagodzinski L, Michael $\mathrm{N}$, Spudich S, et al. Central nervous system viral invasion and inflammation during acute HIV infection. J Infect Dis. 2012;206:275-82.

16. Winston A, Spudich S. Cognitive disorders in people living with HIV. Lancet HIV. 2020;7:e504-13.

17. Nalbandian A, Sehgal K, Gupta A, Madhavan MV, McGroder C, Stevens JS, Cook JR, Nordvig AS, Shalev D, Sehrawat TS, et al. Post-acute COVID-19 syndrome. Nat Med. 2021. https:// doi.org/10.1038/s41591-021-01283-z.

18. Hellmuth J, Barnett TA, Asken BM, Kelly JD, Torres L, Stephens ML, Greenhouse B, Martin JN, Chow FC, Deeks SG, et al. Persistent COVID-19-associated neurocognitive symptoms in non-hospitalized patients. J Neurovirol. 2021;27:191-5.

19.• Graham EL, Clark JR, Orban ZS, Lim PH, Szymanski AL, Taylor C, DiBiase RM, Jia DT, Balabanov R, Ho SU, et al. Persistent neurologic symptoms and cognitive dysfunction in non-hospitalized Covid-19 "long haulers." Ann Clin Transl Neurol. 2021. https://doi.org/10.1002/acn3.51350. ()

20. Zubair AS, McAlpine LS, Gardin T, Farhadian S, Kuruvilla DE, Spudich S. Neuropathogenesis and neurologic manifestations of the coronaviruses in the age of coronavirus disease 2019: a review. JAMA Neurol. 2020;77:1018-27.

21. Jasne AS, Chojecka P, Maran I, Mageid R, Eldokmak M, Zhang Q, Nystrom K, Vlieks K, Askenase M, Petersen N, et al. Stroke 
code presentations, interventions, and outcomes before and during the COVID-19 pandemic. Stroke. 2020;51:2664-73.

22. Harapan BN, Yoo HJ. Neurological symptoms, manifestations, and complications associated with severe acute respiratory syndrome coronavirus 2 (SARS-CoV-2) and coronavirus disease 19 (COVID-19). J Neurol. 2021. https://doi.org/10.1007/ s00415-021-10406-y.

23. Song E, Chow RD, Jiang R, Zamecnik CR, Loudermilk RP, Dai Y, Liu F, Geng B, Chiarella J, Israelow B, et al. Immunologically distinct responses occur in the CNS of COVID-19 patients. bioRxiv. 2020. https://doi.org/10.1101/2020.09.11.293464.

24. Varatharaj A, Thomas N, Ellul MA, Davies NWS, Pollak TA, Tenorio EL, Sultan M, Easton A, Breen G, Zandi M, et al. Neurological and neuropsychiatric complications of COVID-19 in 153 patients: a UK-wide surveillance study. Lancet Psychiatry. 2020;7:875-82.

25. Mao L, Jin H, Wang M, Hu Y, Chen S, He Q, Chang J, Hong C, Zhou Y, Wang D, et al. Neurologic manifestations of hospitalized patients with coronavirus disease 2019 in Wuhan, China. JAMA Neurol. 2020;77:683-90.

26. Frontera JA, Sabadia S, Lalchan R, Fang T, Flusty B, Millar-Vernetti P, Snyder T, Berger S, Yang D, Granger A, et al. A prospective study of neurologic disorders in hospitalized patients with COVID-19 in New York City. Neurology. 2021;96:e575-86. Describes acute neurologic manifestations of SARS-CoV-2 infection in New York City.

27. Helms J, Kremer S, Merdji H, Clere-Jehl R, Schenck M, Kummerlen C, Collange O, Boulay C, Fafi-Kremer S, Ohana M, et al. Neurologic features in severe SARS-CoV-2 infection. N Engl J Med. 2020;382:2268-70.

28. Eskandar EN, Altschul DJ, de la Garza RR, Cezayirli P, Unda SR, Benton J, Dardick J, Toma A, Patel N, Malaviya A, et al. Neurologic syndromes predict higher in-hospital mortality in COVID-19. Neurology. 2021;96:e1527-38.

29. Ellul MA, Benjamin L, Singh B, Lant S, Michael BD, Easton A, Kneen R, Defres S, Sejvar J, Solomon T. Neurological associations of COVID-19. Lancet Neurol. 2020;19:767-83.

30. Moriguchi T, Harii N, Goto J, Harada D, Sugawara H, Takamino J, Ueno M, Sakata H, Kondo K, Myose N, et al. A first case of meningitis/encephalitis associated with SARS-Coronavirus-2. Int J Infect Dis. 2020;94:55-8.

31. Bernard-Valnet R, Pizzarotti B, Anichini A, Demars Y, Russo E, Schmidhauser M, Cerutti-Sola J, Rossetti AO, Du Pasquier R. Two patients with acute meningoencephalitis concomitant with SARS-CoV-2 infection. Eur J Neurol. 2020;27:e43-4.

32. Mukerji SS, Solomon IH. What can we learn from brain autopsies in COVID-19? Neurosci Lett. 2021;742:135528.

33. Solomon IH, Normandin E, Bhattacharyya S, Mukerji SS, Keller K, Ali AS, Adams G, Hornick JL, Padera RF Jr, Sabeti P. Neuropathological features of Covid-19. N Engl J Med. 2020;383:98992. Describes brain histopathology in a series of individuals who died from SARS-CoV-2 infection.

34. Lee M-H, Perl DP, Nair G, Li W, Maric D, Murray H, Dodd SJ, Koretsky AP, Watts JA, Cheung V, et al. Microvascular injury in the brains of patients with Covid-19. N Engl J Med. 2021;384:481-3.

35. Merkler AE, Parikh NS, Mir S, Gupta A, Kamel H, Lin E, Lantos J, Schenck EJ, Goyal P, Bruce SS, et al. Risk of ischemic stroke in patients with coronavirus disease 2019 (COVID-19) vs patients with influenza. JAMA Neurol. 2020. https://doi.org/ 10.1001/jamaneurol.2020.2730.

36. Li Y, Li M, Wang M, Zhou Y, Chang J, Xian Y, Wang D, Mao L, Jin $\mathrm{H}, \mathrm{Hu}$ B. Acute cerebrovascular disease following COVID19: a single center, retrospective, observational study. Stroke Vasc Neurol. 2020;5:279-84.
37. Oxley TJ, Mocco J, Majidi S, Kellner CP, Shoirah H, Singh IP, De Leacy RA, Shigematsu T, Ladner TR, Yaeger KA, et al. Large-vessel stroke as a presenting feature of Covid-19 in the young. N Engl J Med. 2020;382:e60.

38. Escalard S, Maïer B, Redjem H, Delvoye F, Hébert S, Smajda S, Ciccio G, Desilles J-P, Mazighi M, Blanc R, et al. Treatment of acute ischemic stroke due to large vessel occlusion with COVID19: experience from Paris. Stroke. 2020;51:2540-3.

39. Peluso MJ, Kelly JD, Lu S, Goldberg SA, Davidson MC, Mathur S, Durstenfeld MS, Spinelli MA, Hoh R, Tai V, et al. Rapid implementation of a cohort for the study of post-acute sequelae of SARS-CoV-2 infection/COVID-19. medRxiv. 2021. https:// doi.org/10.1101/2021.03.11.21252311.

40. Jacobson KB, Rao M, Bonilla H, Subramanian A, Hack I, Madrigal M, Singh U, Jagannathan P, Grant P. Patients with uncomplicated COVID-19 have long-term persistent symptoms and functional impairment similar to patients with severe COVID-19: a cautionary tale during a global pandemic. Clin Infect Dis. 2021. https://doi.org/10.1093/cid/ciab103.

41. Logue JK, Franko NM, McCulloch DJ, McDonald D, Magedson A, Wolf CR, Chu HY. Sequelae in adults at 6 months after COVID-19 infection. JAMA Netw Open. 2021;4:e210830.

42. Tenforde MW, Kim SS, Lindsell CJ, Billig Rose E, Shapiro NI, Files DC, Gibbs KW, Erickson HL, Steingrub JS, Smithline HA, et al. Symptom duration and risk factors for delayed return to usual health among outpatients with COVID-19 in a multistate health care systems network - United States, MarchJune 2020. MMWR Morb Mortal Wkly Rep. 2020;69:993-8.

43. Carvalho-Schneider C, Laurent E, Lemaignen A, Beaufils E, Bourbao-Tournois C, Laribi S, Flament T, Ferreira-Maldent N, Bruyère $\mathrm{F}$, Stefic $\mathrm{K}$, et al. Follow-up of adults with noncritical COVID-19 two months after symptom onset. Clin Microbiol Infect. 2020. https://doi.org/10.1016/j.cmi.2020.09.052.

44. Huang C, Huang L, Wang Y, Li X, Ren L, Gu X, Kang L, Guo L, Liu M, Zhou X, et al. 6-month consequences of COVID-19 in patients discharged from hospital: a cohort study. Lancet. 2021;397:220-32.

45•• Carfì A, Bernabei R, Landi F. Gemelli Against COVID-19 Post-Acute Care Study Group: Persistent symptoms in patients after acute COVID-19. JAMA. 2020;324:603-5. Comprehensive review of post-acute sequelae of SARS-CoV-2 infection (PASC).

46. Sudre CH, Murray B, Varsavsky T, Graham MS, Penfold RS, Bowyer RC, Pujol JC, Klaser K, Antonelli M, Canas LS, et al. Attributes and predictors of long COVID. Nat Med. 2021. https://doi.org/10.1038/s41591-021-01292-y.

47. Ayoubkhani D. Prevalence of ongoing symptoms following coronavirus (COVID-19) infection in the UK - Office for National Statistics. 2021.

48. Taquet M, Geddes JR, Husain M, Luciano S, Harrison PJ. 6-month neurological and psychiatric outcomes in 236379 survivors of COVID-19: a retrospective cohort study using electronic health records. Lancet Psychiatry. 2021. https://doi. org/10.1016/S2215-0366(21)00084-5.

49. Davis HE, Assaf GS, McCorkell L, Wei H, Low RJ, Re'em Y, Redfield S, Austin JP, Akrami A. Characterizing long COVID in an international cohort: 7 months of symptoms and their impact. medRxiv. 2020.

50. Dauby N. Potential impact of COVID-19 in people living with HIV: experience from previous 21 st century coronaviruses epidemics. AIDS. 2020;34:1255-6.

51. Charre C, Icard V, Pradat P, Brochier C, Lina B, Chidiac C, Cotte L. COVID-19 attack rate in HIV-infected patients and in PrEP users. AIDS 2020, Publish Ahead of Print.

52. Huang J, Xie N, Hu X, Yan H, Ding J, Liu P, Ma H, Ruan L, $\mathrm{Li} \mathrm{G}, \mathrm{He} \mathrm{N}$, et al. Epidemiological, virological and serological 
features of COVID-19 cases in people living with HIV in Wuhan City: a population-based cohort study. Clin Infect Dis. 2020. https://doi.org/10.1093/cid/ciaa1186.

53. Inciarte A, Gonzalez-Cordon A, Rojas J, Torres B, de Lazzari E, de la Mora L, Martinez-Rebollar M, Laguno M, Callau P, Gonzalez-Navarro A, et al. Clinical characteristics, risk factors, and incidence of symptomatic coronavirus disease 2019 in a large cohort of adults living with HIV: a single-center, prospective observational study. AIDS. 2020;34:1775-80.

54. Del Amo J, Polo R, Moreno S, Díaz A, Martínez E, Arribas JR, Jarrín I, Hernán MA. The Spanish HIV/COVID-19 Collaboration: Incidence and severity of COVID-19 in HIV-positive persons receiving antiretroviral therapy : a cohort study. Ann Intern Med. 2020;173:536-41

55. Ho H-E, Peluso MJ, Margus C, Matias Lopes JP, He C, Gaisa MM, Osorio G, Aberg JA, Mullen MP. Clinical outcomes and immunologic characteristics of coronavirus disease 2019 in people with human immunodeficiency virus. J Infect Dis. 2021;223:403-8.

56. Härter G, Spinner CD, Roider J, Bickel M, Krznaric I, Grunwald S, Schabaz F, Gillor D, Postel N, Mueller MC, et al. COVID-19 in people living with human immunodeficiency virus: a case series of 33 patients. Infection. 2020;48:681-6.

57. Vizcarra P, Pérez-Elías MJ, Quereda C, Moreno A, Vivancos MJ, Dronda F, Casado JL. COVID-19 ID Team: Description of COVID-19 in HIV-infected individuals: a single-centre, prospective cohort. Lancet HIV. 2020;7:e554-64.

58. Shalev N, Scherer M, LaSota ED, Antoniou P, Yin MT, Zucker J, Sobieszczyk ME. Clinical characteristics and outcomes in people living with human immunodeficiency virus hospitalized for coronavirus disease 2019. Clin Infect Dis. 2020;71:2294-7.

59. Dandachi D, Geiger G, Montgomery MW, Karmen-Tuohy S, Golzy M, Antar AAR, Llibre JM, Camazine M, Díaz-De Santiago A, Carlucci PM, et al. Characteristics, comorbidities, and outcomes in a multicenter registry of patients with HIV and coronavirus disease-19. Clin Infect Dis. 2020. https://doi.org/ 10.1093/cid/ciaa1339.

60. Boulle A, Davies M-A, Hussey H, Ismail M, Morden E, Vundle Z, Zweigenthal V, Mahomed H, Paleker M, Pienaar D, et al. Risk factors for COVID-19 death in a population cohort study from the Western Cape Province, South Africa. Clin Infect Dis. 2020. https://doi.org/10.1093/cid/ciaa1198.

61. amfAR. New amfAR grants target intersection of HIV and COVID-19. Available at: https://www.amfar.org/amfAR-GrantsTarget-Intersection-of-HIV-and-COVID-19/. Accessed Apr 24 2021.

62. Bandera A, Taramasso L, Bozzi G, Muscatello A, Robinson JA, Burdo TH, Gori A. HIV-associated neurocognitive impairment in the modern ART era: are we close to discovering reliable biomarkers in the setting of virological suppression? Front Aging Neurosci. 2019;11:187.

63. Cysique LAJ, Maruff P, Brew BJ. The neuropsychological profile of symptomatic AIDS and ADC patients in the pre-HAART era: a meta-analysis. J Int Neuropsychol Soc. 2006;12:368-82.

64. Spudich S, Robertson KR, Bosch RJ, Gandhi RT, Cyktor JC, Mar H, Macatangay BJ, Lalama CM, Rinaldo C, Collier AC, et al. Persistent HIV-infected cells in cerebrospinal fluid are associated with poorer neurocognitive performance. J Clin Invest. 2019;129:3339-46.

65. Gaebler C, Wang Z, Lorenzi JCC, Muecksch F, Finkin S, Tokuyama M, Cho A, Jankovic M, Schaefer-Babajew D, Oliveira TY, et al. Evolution of antibody immunity to SARS-CoV-2. Nature. 2021;591:639-44.

66. Helleberg M, Niemann CU, Moestrup KS, Kirk O, Lebech A-M, Lane C, Lundgren J. Persistent COVID-19 in an immunocompromised patient temporarily responsive to two courses of remdesivir therapy. J Infect Dis. 2020;222:1103-7.

67. Choi B, Choudhary MC, Regan J, Sparks JA, Padera RF, Qiu X, Solomon IH, Kuo H-H, Boucau J, Bowman K, et al. Persistence and evolution of SARS-CoV-2 in an immunocompromised host. N Engl J Med. 2020;383:2291-3.

68. Zheng S, Fan J, Yu F, Feng B, Lou B, Zou Q, Xie G, Lin S, Wang R, Yang X, et al. Viral load dynamics and disease severity in patients infected with SARS-CoV-2 in Zhejiang province, China, January-March 2020: retrospective cohort study. BMJ. 2020;369:m1443.

69. Arbour N, Ekandé S, Côté G, Lachance C, Chagnon F, Tardieu M, Cashman NR, Talbot PJ. Persistent infection of human oligodendrocytic and neuroglial cell lines by human coronavirus 229E. J Virol. 1999;73:3326-37.

70. Bender SJ, Weiss SR. Pathogenesis of murine coronavirus in the central nervous system. J Neuroimmune Pharmacol. 2010;5:336-54.

71. Burdo TH, Lentz MR, Autissier P, Krishnan A, Halpern E, Letendre S, Rosenberg ES, Ellis RJ, Williams KC. Soluble CD163 made by monocyte/macrophages is a novel marker of HIV activity in early and chronic infection prior to and after anti-retroviral therapy. J Infect Dis. 2011;204:154-63.

72. Neuhaus J, Jacobs DR Jr, Baker JV, Calmy A, Duprez D, La Rosa A, Kuller LH, Pett SL, Ristola M, Ross MJ, et al. Markers of inflammation, coagulation, and renal function are elevated in adults with HIV infection. J Infect Dis. 2010;201:1788-95.

73. O'Halloran JA, Dunne E, Gurwith M, Lambert JS, Sheehan GJ, Feeney ER, Pozniak A, Reiss P, Kenny D, Mallon P. The effect of initiation of antiretroviral therapy on monocyte, endothelial and platelet function in HIV-1 infection. HIV Med. 2015;16:608-19.

74. Méndez-Lagares G, Romero-Sánchez MC, Ruiz-Mateos E, Genebat M, Ferrando-Martínez S, Muñoz-Fernández MÁ, Pacheco YM, Leal M. Long-term suppressive combined antiretroviral treatment does not normalize the serum level of soluble CD14. J Infect Dis. 2013;207:1221-5.

75. Burdo TH, Weiffenbach A, Woods SP, Letendre S, Ellis RJ, Williams KC. Elevated sCD163 in plasma but not cerebrospinal fluid is a marker of neurocognitive impairment in HIV infection. AIDS. 2013;27:1387-95.

76. Imp BM, Rubin LH, Tien PC, Plankey MW, Golub ET, French AL, Valcour VG. Monocyte activation is associated with worse cognitive performance in HIV-infected women with virologic suppression. J Infect Dis. 2017;215:114-21.

77. Lyons JL, Uno H, Ancuta P, Kamat A, Moore DJ, Singer EJ Morgello S, Gabuzda D. Plasma SCD14 is a biomarker associated with impaired neurocognitive test performance in attention and learning domains in HIV infection. J Acquir Immune Defic Syndr. 2011;57:371-9.

78. Laing AG, Lorenc A, del Molino del Barrio I, Das A, Fish M, Monin L, Muñoz-Ruiz M, McKenzie DR, Hayday TS, Francos-Quijorna I, et al. A dynamic COVID-19 immune signature includes associations with poor prognosis. Nat Med. 2020;26:1623-35.

79. Lucas C, Wong P, Klein J, Castro TBR, Silva J, Sundaram M, Ellingson MK, Mao T, Oh JE, Israelow B, et al. Longitudinal analyses reveal immunological misfiring in severe COVID-19. Nature. 2020;584:463-9.

80. Del Valle DM, Kim-Schulze S, Huang H-H, Beckmann ND, Nirenberg S, Wang B, Lavin Y, Swartz TH, Madduri D, Stock A, et al. An inflammatory cytokine signature predicts COVID19 severity and survival. Nat Med. 2020;26:1636-43.

81. Edén A, Kanberg N, Gostner J, Fuchs D, Hagberg L, Andersson L-M, Lindh M, Price RW, Zetterberg H, Gisslén M. CSF 
biomarkers in patients with COVID-19 and neurologic symptoms: a case series. Neurology. 2021;96:e294-300.

82. Bonny TS, Patel EU, Zhu X, Bloch EM, Grabowski MK, Abraham AG, Littlefield K, Shrestha R, Benner SE, Laeyendecker $\mathrm{O}$, et al. Cytokine and chemokine levels in coronavirus disease 2019 convalescent plasma. Open Forum Infect Dis. 2021;8:ofaa574. Provides mechanistic rationale for persistentinflammation as a potential driver of post-acute sequelae of SARS-CoV-2 infection.

83.• Song E, Zhang C, Israelow B, Lu-Culligan A, Prado AV, Skriabine S, Lu P, Weizman O-E, Liu F, Dai Y, et al.: Neuroinvasion of SARS-CoV-2 in human and mouse brain. J Exp Med. 2021;218. Provides mechanistic rationale for viral invasion (and potential antigen persistence) as a driver of CNS manifestations of SARS-CoV-2 infection.

84. Paniz-Mondolfi A, Bryce C, Grimes Z, Gordon RE, Reidy J, Lednicky J, Sordillo EM, Fowkes M. Central nervous system involvement by severe acute respiratory syndrome coronavirus-2 (SARS-CoV-2). J Med Virol. 2020;92:699-702.

85. Lewis A, Frontera J, Placantonakis DG, Lighter J, Galetta S, Balcer L, Melmed KR. Cerebrospinal fluid in COVID-19: a systematic review of the literature. J Neurol Sci. 2021;421:117316. Review identifying limited evidence of SARS-CoV-2 recovered from the cerebrospinal fluid.

86. Spudich S, Gisslen M, Hagberg L, Lee E, Liegler T, Brew B, Fuchs D, Tambussi G, Cinque P, Hecht FM, et al. Central nervous system immune activation characterizes primary human immunodeficiency virus 1 infection even in participants with minimal cerebrospinal fluid viral burden. J Infect Dis. 2011;204:753-60.

87. Spudich SS, Nilsson AC, Lollo ND, Liegler TJ, Petropoulos CJ, Deeks SG, Paxinos EE, Price RW. Cerebrospinal fluid HIV infection and pleocytosis: relation to systemic infection and antiretroviral treatment. BMC Infect Dis. 2005;5:98.

88. Chan P, Kerr SJ, Kroon E, Colby D, Sacdalan C, Hellmuth J, Reiss P, Vasan S, Ananworanich J, Valcour V, et al. Cognitive trajectories after treatment in acute HIV infection. AIDS. 2021;35.

89. Hellmuth J, Slike BM, Sacdalan C, Best J, Kroon E, Phanuphak N, Fletcher JLK, Prueksakaew P, Jagodzinski LL, Valcour V, et al. Very early initiation of antiretroviral therapy during acute HIV infection is associated with normalized levels of immune activation markers in cerebrospinal fluid but not in plasma. $\mathrm{J}$ Infect Dis. 2019;220.

90. Simioni S, Cavassini M, Annoni J-M, Rimbault Abraham A, Bourquin I, Schiffer V, Calmy A, Chave J-P, Giacobini E, Hirschel B, et al. Cognitive dysfunction in HIV patients despite long-standing suppression of viremia. AIDS. 2010;24:1243-50.

91. Yuan L, Liu A, Qiao L, Sheng B, Xu M, Li W, Chen D. The relationship of CSF and plasma cytokine levels in HIV infected patients with neurocognitive impairment. Biomed Res Int. 2015;2015:506872.

92. Peterson J, Gisslen M, Zetterberg H, Fuchs D, Shacklett BL, Hagberg L, Yiannoutsos CT, Spudich SS, Price RW. Cerebrospinal fluid (CSF) neuronal biomarkers across the spectrum of HIV infection: hierarchy of injury and detection. PLoS One. 2014;9:e116081.

93. Kanberg N, Ashton NJ, Andersson L-M, Yilmaz A, Lindh M, Nilsson S, Price RW, Blennow K, Zetterberg H, Gisslén M. Neurochemical evidence of astrocytic and neuronal injury commonly found in COVID-19. Neurology. 2020;95:e1754-9. Provides mechanistic rationale for neuronal injury as a potential driver of neurologic sequelae from SARS-CoV-2 infection.

94. Zandman-Goddard G, Shoenfeld Y. HIV and autoimmunity. Autoimmun Rev. 2002;1:329-37.
95. Peluso MJ, Chen J, Munter S, Reed A, Teraoka J, Eshun-Wilson I, Henrich TJ, Chin-Hong PV. Outcomes of immunomodulatory and biologic therapy in people living with HIV. AIDS. 2020;34:1171-9.

96. Virot E, Duclos A, Adelaide L, Miailhes P, Hot A, Ferry T, Seve P. Autoimmune diseases and HIV infection: a cross-sectional study. Medicine. 2017;96:e5769.

97. Boehme AK, Ranawat P, Luna J, Kamel H, Elkind MSV. Risk of acute stroke after hospitalization for sepsis: a case-crossover study. Stroke. 2017;48:574-80.

98. Elkind MSV, Carty CL, O’Meara ES, Lumley T, Lefkowitz D, Kronmal RA, Longstreth WT Jr. Hospitalization for infection and risk of acute ischemic stroke: the Cardiovascular Health Study. Stroke. 2011;42:1851-6.

99. Becker JT, Kingsley L, Mullen J, Cohen B, Martin E, Miller EN, Ragin A, Sacktor N, Selnes OA, Visscher BR, et al. Vascular risk factors, HIV serostatus, and cognitive dysfunction in gay and bisexual men. Neurology. 2009;73:1292-9.

100. Wright EJ, Grund B, Robertson K, Brew BJ, Roediger M, Bain MP, Drummond F, Vjecha MJ, Hoy J, Miller C, et al. Cardiovascular risk factors associated with lower baseline cognitive performance in HIV-positive persons. Neurology. 2010;75:864-73.

101. Elkind MSV, Ramakrishnan P, Moon YP, Boden-Albala B, Liu KM, Spitalnik SL, Rundek T, Sacco RL, Paik MC. Infectious burden and risk of stroke: the northern Manhattan study. Arch Neurol. 2010;67:33-8.

102. Carrico AW, Horvath KJ, Grov C, Moskowitz JT, Pahwa S, Pallikkuth S, Hirshfield S. Double jeopardy: methamphetamine use and HIV as risk factors for COVID-19. AIDS Behav. 2020;24:3020-3.

103. Norman LR, Basso M. An update of the review of neuropsychological consequences of HIV and substance abuse: a literature review and implications for treatment and future research. Curr Drug Abuse Rev. 2015;8:50-71.

104. Weber E, Morgan EE, Iudicello JE, Blackstone K, Grant I, Ellis RJ, Letendre SL, Little S, Morris S, Smith DM, et al. Substance use is a risk factor for neurocognitive deficits and neuropsychiatric distress in acute and early HIV infection. J Neurovirol. 2013;19:65-74

105. Chen LH, Peterson J, Robertson K, Fuchs D, Price R, Spudich S. Past substance use affects central nervous system (CNS) inflammation in human immunodeficiency virus infection. Open Forum Infect Dis. 2016;3.

106. Carrico AW, Hunt PW, Neilands TB, Dilworth SE, Martin JN, Deeks SG, Riley ED. Stimulant use and viral suppression in the era of universal antiretroviral therapy. J Acquir Immune Defic Syndr. 2019;80:89-93.

107. Carrico AW, Cherenack EM, Roach ME, Riley ED, Oni O, Dilworth SE, Shoptaw S, Hunt P, Roy S, Pallikkuth S, et al. Substance-associated elevations in monocyte activation among methamphetamine users with treated HIV infection. AIDS. 2018;32:767.

108. Frydrych LM, Bian G, O'Lone DE, Ward PA, Delano MJ. Obesity and type 2 diabetes mellitus drive immune dysfunction, infection development, and sepsis mortality. J Leukoc Biol. 2018;104:525-34.

109. Popkin BM, Du S, Green WD, Beck MA, Algaith T, Herbst $\mathrm{CH}$, Alsukait RF, Alluhidan M, Alazemi N, Shekar M. Individuals with obesity and COVID-19: a global perspective on the epidemiology and biological relationships. Obes Rev. 2020;21:e13128.

110. Apicella M, Campopiano MC, Mantuano M, Mazoni L, Coppelli A, Del Prato S. COVID-19 in people with diabetes: understanding the reasons for worse outcomes. Lancet Diabetes Endocrinol. 2020;8:782-92. 
111. Sattler FR, He J, Letendre S, Wilson C, Sanders C, Heaton R, Ellis R, Franklin D, Aldrovandi G, Marra CM, et al. Abdominal obesity contributes to neurocognitive impairment in HIVinfected patients with increased inflammation and immune activation. J Acquir Immune Defic Syndr. 2015;68:281-8.

112. D'Souza G, Springer G, Gustafson D, Kassaye S, Alcaide ML, Ramirez C, Sharma A, Palella FJ, Tien PC, Detels R, et al. COVID-19 symptoms and SARS-CoV-2 infection among people living with HIV in the US: the MACS/WIHS combined cohort study. HIV Res Clin Pract. 2020;21:130-9.

113. D’Souza G, Bhondoekhan F, Benning L, Margolick JB, Adedimeji AA, Adimora AA, Alcaide ML, Cohen MH, Detels R, Friedman MR, et al. Characteristics of the MACS-WIHS Combined Cohort Study: opportunities for research on aging with HIV in the longest US observational study of HIV. Am J Epidemiol. 2021. https://doi.org/10.1093/aje/kwab050.

114. Parpia AS, Martinez I, El-Sayed AM, Wells CR, Myers L, Duncan J, Collins J, Fitzpatrick MC, Galvani AP, Pandey A. Racial disparities in COVID-19 mortality across Michigan, United States. EClinicalMedicine. 2021;33:100761.

115. Azar KMJ, Shen Z, Romanelli RJ, Lockhart SH, Smits K, Robinson S, Brown S, Pressman AR. Disparities in outcomes among COVID-19 patients in a large health care system in California: study estimates the COVID-19 infection fatality rate at the US county level. Health Aff. 2020;39:1253-62.

116. Macias Gil R, Marcelin JR, Zuniga-Blanco B, Marquez C, Mathew T, Piggott DA. COVID-19 pandemic: disparate health impact on the Hispanic/Latinx population in the United States. J Infect Dis. 2020;222:1592-5.

117. Tedaldi EM, Minniti NL, Fischer T. HIV-associated neurocognitive disorders: the relationship of HIV infection with physical and social comorbidities. Biomed Res Int. 2015;2015:641913.

118. Haddow LJ, Laverick R, Daskalopoulou M, McDonnell J, Lampe FC, Gilson R, Speakman A, Antinori A, Balestra P, Bruun T, et al. Multicenter European prevalence study of neurocognitive impairment and associated factors in HIV positive patients. AIDS Behav. 2018;22:1573-83.

119. Arentoft A, Byrd D, Monzones J, Coulehan K, Fuentes A, Rosario A, Miranda C, Morgello S, Rivera Mindt M. Socioeconomic status and neuropsychological functioning: associations in an ethnically diverse HIV+ cohort. Clin Neuropsychol. 2015;29:232-54.

120. Possin KL, Tsoy E, Windon CC. Perils of race-based norms in cognitive testing: the case of former NFL players. JAMA Neurol. 2020. https://doi.org/10.1001/jamaneurol.2020.4763.

121. Kamalyan L, Hussain MA, Diaz MM, Umlauf A, Franklin DR, Cherner M, Rivera Mindt M, Artiola I, Fortuny L, Grant I, Heaton RK, et al. Neurocognitive impairment in Spanish-speaking Latinos living with HIV in the US: application of the neuropsychological norms for the US-Mexico border region in Spanish (NP-NUMBRS). Clin Neuropsychol. 2021;35:433-52.

122. Cysique LA, Jin H, Franklin DR Jr, Morgan EE, Shi C, Yu X, Wu Z, Taylor MJ, Marcotte TD, Letendre S, et al. Neurobehavioral effects of HIV-1 infection in China and the United States: a pilot study. J Int Neuropsychol Soc. 2007;13:781-90.

123. Maki PM, Rubin LH, Springer G, Seaberg EC, Sacktor N, Miller EN, Valcour V, Young MA, Becker JT, Martin EM, et al. Differences in cognitive function between women and men with HIV. J Acquir Immune Defic Syndr. 2018;79:101-7.

124. Robertson K, Jiang H, Evans SR, Marra CM, Berzins B, Hakim J, Sacktor N, Silva MT, Campbell TB, Nair A, et al. International neurocognitive normative study: neurocognitive comparison data in diverse resource-limited settings: AIDS Clinical Trials Group A5271. J Neurovirol. 2016;22:472-8.

125. Robertson KR, Jiang H, Kumwenda J, Supparatpinyo K, Marra CM, Berzins B, Hakim J, Sacktor N, Campbell TB, Schouten J, et al. Human immunodeficiency virus-associated neurocognitive impairment in diverse resource-limited settings. Clin Infect Dis. 2019;68:1733-8.

126. Moonis G, Filippi CG, Kirsch CFE, Mohan S, Stein EG, Hirsch JA, Mahajan A. The spectrum of neuroimaging findings on CT and MRI in adults with coronavirus disease (COVID-19). AJR Am J Roentgenol. 2020. https://doi.org/10.2214/AJR.20.24839.

127. Katal S, Gholamrezanezhad A. Neuroimaging findings in COVID-19: a narrative review. Neurosci Lett. 2021;742:135529.

128. Lu Y, Li X, Geng D, Mei N, Wu P-Y, Huang C-C, Jia T, Zhao Y, Wang D, Xiao A, et al. Cerebral micro-structural changes in COVID-19 patients - an MRI-based 3-month follow-up study. EClinicalMedicine. 2020;25:100484.

129. Peluso MJ, Valcour V, Ananworanich J, Sithinamsuwan P, Chalermchai T, Fletcher JLK, Lerdlum S, Chomchey N, Slike B, Sailasuta N, et al. Absence of cerebrospinal fluid signs of neuronal injury before and after immediate antiretroviral therapy in acute HIV infection. J Infect Dis. 2015;212:1759-67.

130. Sanford R, Fellows LK, Ances BM, Collins DL. Association of brain structure changes and cognitive function with combination antiretroviral therapy in HIV-positive individuals. JAMA Neurol. 2018;75:72-9.

131. Callen AL, Dupont SM, Pyne J, Talbott J, Tien P, Calabrese E, Saloner D, Chow FC, Narvid J. The regional pattern of abnormal cerebrovascular reactivity in HIV-infected, virally suppressed women. J Neurovirol. 2020;26:734-42.

132. Chaganti JR, Heinecke A, Gates TM, Moffat KJ, Brew BJ. Functional connectivity in virally suppressed patients with HIV-associated neurocognitive disorder: a resting-state analysis. AJNR Am J Neuroradiol. 2017;38:1623-9.

133. Su T, Caan MWA, Wit FWNM, Schouten J, Geurtsen GJ, Cole JH, Sharp DJ, Vos FM, Prins M, Portegies P, et al. White matter structure alterations in HIV-1-infected men with sustained suppression of viraemia on treatment. AIDS. 2016;30:311-22.

134. Baden LR, El Sahly HM, Essink B, Kotloff K, Frey S, Novak R, Diemert D, Spector SA, Rouphael N, Creech CB, et al. Efficacy and safety of the mRNA-1273 SARS-CoV-2 vaccine. N Engl J Med. 2021;384:403-16.

135. Polack FP, Thomas SJ, Kitchin N, Absalon J, Gurtman A, Lockhart S, Perez JL, Pérez Marc G, Moreira ED, Zerbini C, et al. Safety and efficacy of the BNT162b2 mRNA Covid-19 vaccine. N Engl J Med. 2020;383:2603-15.

136. Sadoff J, Le Gars M, Shukarev G, Heerwegh D, Truyers C, de Groot AM, Stoop J, Tete S, Van Damme W, Leroux-Roels I, et al. Interim results of a phase 1-2a trial of Ad26.COV2.S Covid-19 vaccine. N Engl J Med. 2021. https://doi.org/10.1056/ NEJMoa2034201.

137. Callaway E, Mallapaty S. Novavax offers first evidence that COVID vaccines protect people against variants. Nature. 2021;590:17.

Publisher's Note Springer Nature remains neutral with regard to jurisdictional claims in published maps and institutional affiliations. 